Cinémas

Revue d'études cinématographiques

Journal of Film Studies

\title{
The Canadian Experimental Camera-Child
}

\section{Loretta Czernis}

Volume 2, numéro 1, automne 1991

URI : https://id.erudit.org/iderudit/1001057ar

DOI : https://doi.org/10.7202/1001057ar

Aller au sommaire du numéro

Éditeur(s)

Cinémas

ISSN

1181-6945 (imprimé)

1705-6500 (numérique)

Découvrir la revue

Citer cet article

Czernis, L. (1991). The Canadian Experimental Camera-Child. Cinémas, 2(1),

155-167. https://doi.org/10.7202/1001057ar

\section{Résumé de l'article}

Le cinéma expérimental n'est pas très visible, mais il a eu un impact sur le cinéma en général, tant du point de vue artistique que technique. Les expérimentations conceptuelles et techniques empruntent différentes voies dans les films, suivant leurs contextes culturels. Les cinéastes expérimentaux canadiens ont filmé, en imaginant ce que nous aurions pu être, notre incapacité à nous inventer. Ils sont influencés par les cinéastes d'avant-garde européens et américains et leur rapport à la caméra comme une entité " vivante » et technologique. 


\title{
The Canadian Experimental Camera-Child
}

\section{Loretta Czernis}

\begin{abstract}
RÉSUMÉ
Le cinéma expérimental n'est pas très visible, mais il a eu un impact sur le cinéma en général, tant du point de vue artistique que technique. Les expérimentations conceptuelles et techniques empruntent différentes voies dans les films, suivant leurs contextes culturels. Les cinéastes expérimentaux canadiens ont filmé, en imaginant ce que nous aurions pu être, notre incapacité à nous inventer. Ils sont influencés par les cinéastes d'avantgarde européens et américains et leur rapport à la caméra comme une entité «vivante» et technologique.
\end{abstract}

\begin{abstract}
Experimental film is not highly visible but it has had an impact on cinema as both art and technique. Conceptual and technical experiments in film take many forms depending on their cultural contexts. Canadian experimental filmmakers have recorded our inability to invent ourselves as they imagine that we might have been. They are influenced by European and American avant-garde filmmakers and their relationship to the camera as a "living" and technological entity.
\end{abstract}

We often assume that film is institutionalized, forgetting the films that lie on the margin of the Hollywood industry. These films are made by artists who, in relation to the formally recognized industry, have little status. Their art is invisible, much like the work in women's crafts. These crafts have only been acknowledged in recent years, through the efforts of artists such as Joyce Wieland and Miriam Shapiro. 
Whether female or male, experimental filmmakers are rendered invisible because they do not have access to the distribution and marketing processes developed by and for film as an institution. The unseen work of these filmmakers can be compared to the still inadequately understood methods of the men and women creatively raising children in the home.

What is a "method"? A difficult question when attempting to understand the ways and means of most experimental filmmakers. Michael Snow is a painter, a sculptor, a metallurgist, a photographer, a filmmaker and a musician. Andy Warhol and Hollis Frampton work in an equally staggering number of media. Each of these artists is informed by all of the art forms that they have been curious enough to master. They move from one to another depending on the mood, or message, or image they wish to create at any given moment, having a variety of methods ready at hand to fit a vision waiting to be realized. And, sometimes their visions in turn change media themselves, for example, when Joyce Wieland paints directly on celluloid as she did for her film Handtinting (1967, 5 1/2 min.), or when Stan Brakhage or Bruce Elder decide to make films which are predominantly visually tactile and not literary, changing the ways in which critics can look at, talk about and write about film. No longer dealing with story films, film theorists are forced by such cinema to extend their vocabulary beyond literary criticism and art history to philosophy, social theory and psychoanalysis. In order to be comprehensive, any study of the Canadian avantgarde should be attentive to the ways in which experimental artists attempt to depict emotional dynamics at the societal level, and the not obvious social dynamics at work in feeling states.

Experimental filmmakers seek solace and hope in their camera experiments. The Europeans have traditionally sought in film technology an escape from human contradictions. American filmmakers have documented the attempted escape by their countrymen from the pain of existence into various forms of numbing self-destruction. Canadian experimental filmmakers have recorded our inability to invent ourselves as we once might have been (they ideally imagine) but their films neither address nor document escape.

The essence of the Canadian intellectual condition is this: it is our fate by virtue of historical circumstance and geographical accident to be forever marginal to the "present-mindedness" of American culture and to be incapable of being more than ambivalent on the cultural legacy of our European past (Kroker, 7-8). 
I will approach the body of European, American and Canadian experimental cinema with a theme which pervades all three. All have developed their directions distinctively; yet each has done so as if nurturing a child. How then has each culture's experimental camera been taught and cared for? Looking at the nurturing strategies of some filmmakers may help us to understand more about the mediating perspective fundamental to Canadian creative imagination. Further, Canadian avant-garde filmmakers have used their ambivalence to create an art form which is born of, but which goes beyond, its dual legacy.

Experimental cinema has produced a new entity, which has been nurtured through childhood and adolescence by Saint-PolRoux, Warhol, Snow and Elder. It has been taught human history, human language, human aesthetics. It has even recorded the lives, joys, sorrows and deaths of its contributing parent-artists Dziga Vertov, Hollis Frampton and Jack Chambers. New cinematic devices can now teach us to remember things which many of us forgot that we knew, and this can occur because of an abundant memory for names, faces, emotions, idiosyncrasies. The simulated nurturance of a machine-life form by avant-garde filmmakers has contributed significantly to social history as well as to art theory.

In Vertov's The Man with The Movie Camera (1929), this Russian filmmaker took his camera everywhere with him, as if it were a baby requiring constant attention. ${ }^{1}$ Not only was the helpless camera dependent on Vertov; he was dependent upon it so that he might record the social reconstruction going on all over Russia. Vertov and hís camera went everywhere together. At first, the camera saw only what Vertov showed it; later, as it grew, it began to develop its own sight (as we watch the camera shutter blink) and its own desires to wander where it wished without always having to be carried around by Papa-Vertov. In Part Six of the film, the camera got up and walked by itself. And where did the camera go on its own? To a huge crowd, to the people Vertov developed his camera into a socially responsible comrade, eager to participate in instituting reforms as the mechanical body from which nothing was hidden. All activities could be recorded and made available to the masses, social practice having become a form of public vision. The camerachild was Vertov's constructivist symbol for an emerging praxis.

Saint-Pol-Roux was a French poet and experimental filmmaker who developed in the 1930's what he called the Cinéma Vivant. His camera was called the Idéoréalisateur, a mechanical object which was capable of dreaming, of recording, and of presenting viewers with its dreams. Saint-Pol-Roux called the films 
which resulted "artworks of Idéoplasticité". The viewer was to be incited to dream by the camera's dreams. The Idéoréalisateur often presented shocking images intended to act as purveyors of an intense vision of collective energy, both presenting and evoking this subliminal energy in audiences: "steps on the road, heartbeats, sounds? The cries of crowds? Human sweat? Do not all these lost and neglected strengths constitute a human radium?" (Caws, 177). ${ }^{2}$ And Saint-Pol-Roux wrote about his cinema as an infant. "The emotion of the mirror is the newborn wailing of the work./What constitutes the work is its effect made plastic" (186). ${ }^{3}$

Although their works contain significant cultural and philosophical differences, both Vertov and Saint-Pol-Roux saw the camera as representing the human subject enhanced, with potentials for political commitment and imaginative play (respectively) fully realized by a machine which does not know ambivalence. They believed in camera technology as a guide which could stimulate and motivate the human will.

Vertov and Saint-Pol-Roux, among others, discovered what could be called a continental cinema of effects, which is quite different from the American experimental cinema. Using the work of Frampton and Warhol as examples, the American cinematic avant-garde could be called a cinema of process, wherein the camera watches, passively observing and recording nonhuman events, by which the camera seems to be rendered impotent. It reverts to a total passivity and develops into an immobile voyeur.

The American experimental filmmaker Hollis Frampton saw photography as his child that died from being too adventurous. In his film (nostalgia) photographs get too close to the stove and burn on an element. But the camera watches this, and learns about such dangers by recording them, so that it will remember. This film is not only about the death of photography. It is about the camera as naive observer and recorder of this and other deaths. The film camera was Frampton's hope, the progeny of photographic technology which could learn to fear photography's adventures. He wanted his camera to learn not to take chances. Representing a catatonic social subject, the camera sees but is powerless to act on what it sees.

The camera-child as observer is an integral part of the cinema of Andy Warhol. In Sleep the camera watches a man sleeping for six hours. In Empire the camera watches the Empire State Building for eight hours. Here the camera matures to adolescence and acquires a sophisticated pornographic sensibility. 
Fascinated by the edifice that was romanticized by machine-age aesthetes, the camera stays up all night with the object of its desire. By creating a film in which a camera falls in love with a building, Warhol has shown one logical, but absurd, result of a numbing consumer culture. When desire becomes something which humans predominantly feel towards objects it is not difficult to imagine that two objects could feel desire for one another (the compulsive consumer her/himself already having become a kind of object).

Between these two, which we could call the active and passive traditions, emerged a Canadian avant-garde. The most innovative of the Canadian experimental filmmakers are not disciples of either the effect or the process approaches. The Canadians have selected elements from both of these traditions and combined them with their own imaginings. The resultant vision has been called romantic and nostalgic, striving to produce remembrance and deep reflection on the particular, but also remaining curiously detached.

Michael Snow for example discovered ways in which he could zoom in and zoom out simultaneously. His most widely acclaimed film is Wavelength (1967) in which a stable camera takes forty-five minutes to zoom in on a picture of waves in an ocean. The tighter the focus becomes, the more of the seeing the camera seems to be doing by itself. This frees the audience from having to look, as in, to self-consciously focus. The photo of the waves stops being a photo to the viewing imagination, once we lose sight of the edges of the picture. Snow continues to zoom in, slowly, making the ocean almost seem to be moving, though the camera remains completely stationary. In this the film finds a beginning in its end, having generated many questions for and about the mind's eye.

In <----> the camera is no longer just an eye, but becomes an entire soma, with a head that slowly pans back and forth. Gradually, over fifty minutes, the speed of the panning increases. At the end of the film, the camera-head changes the direction of its gesture from "no" to "yes"; gestural rhythm is sustained but not time sequence or direction. As well as daring to strip rhythm of components once considered essential to its existence, Snow has turned repetition into an existential dilemma, with the help of the camera. Do the rhythms of our lives remain when we change our pace or our direction? This turns habit into a heart-beat, which keeps working involuntarily, sustaining many shocks, some rhapsodic and others rupturous.

In Standard Time (1967, 8 min.), the camera-soma develops a psyche. The camera does cartwheels around in a room, some- 
times clockwise and sometimes counter-clockwise. These sweeping visual arcs begin to make sense of themselves, as we become privy to the evolution of a mechanical imagination. The camera first documents a woman making a bed; then it sees a turtle; next it sees itself - wires and metal legs; finally, it discovers its fantasy life, fantasizing the woman who was making the bed as now being nude. This is the camera as a child observing the world, and seeing/seeking its own pleasure.

Snow also became interested in his version of the camerachild's awareness of time, and how he might develop this sense to help the child master its adolescence of consciousness and become a mechanical intellectual. He attempted to do this by exploring how reproductions appear to cheat time. Of Snow's One Second in Montreal (1969, 26 min.), P. Adams Sitney wrote: "The absence of internal movement denies the sense of temporal scale that absence magnifies the presence of time as a pure element in the film" (225).

One Second in Montreal is thirty photographs of snow-covered earth in Montreal, each of which was apparently the potential site for a monument, and each of which was shot at 1/30th of a second exposure time. 30 photos at $1 / 30 \mathrm{sec} .=30 / 30=$ one second. This film also plays with time by displaying each of the photographs simply before us, with no camera movement. There is some slight variation in the duration within which we are held to the camera's inspection of each image, but this is hardly noticeable. Each photo is carefully studied by the camera until the camera has taken up all the time it needs in order to remember a photo's content/intent, approximately a minute in each case (if the film is played at silent speed).

The camera begins to develop an awareness of the past work of Snow his teacher/father in the film Side Seat Paintings Slides Sound Film (1970, $20 \mathrm{~min}$.). Snow has made the camera sit and watch a slide-show of his paintings. Snow seems to be attempting here to teach his protégé something about its static brothers and sisters - those objects created before who made this new camera-life possible. This film is also about the post-modern reality of the double simulation. The viewer watches the camera film a slide show, the slides being of Michael Snow's paintings. This is the problem of the simulation as explored during the same period of time by the French thinker Jean Baudrillard, who realized, along with McLuhan, that reproductions were travelling so far from their origins that the discourse on origin was becoming a discourse on nostalgia. 
Another exercise for Snow's camera was to learn about human activities, the most important being speech. In Rameau's Nephew by Diderot (Thanx to Dennis Young) by Wilma Schoen (1974, 285 min.) the camera is shown human singing, laughing, urination, whistling, copulation. It sees people sitting at table, discussing the table, and learning from them what is appropriate and inappropriate in conversations about tables, sex, seeing, hearing and believing, The camera is told, over and over again in catchy rhymes (such as those often used in teaching children how to spell or add), that people believe what they see, but not what they hear. Nearing the end of the film, we watch the camera receive English lessons. Snow is a patient teacher, teaching the camera how some words sound the same but are spelled differently; his example here is "cymbal" and "symbol". Next he explains that some objects have the same name as a colour, but others don't. His example for this is "orange" and a banana, which he calls "yellow" to illustrate the confusion. All of this highlights how confusing the world of human affairs can be for a machine which is enthusiastic but still has a lot to learn. It can research and store information Cartesian-style for us, but it doesn't yet understand how or why. Snow wanted to teach his camera to become conscious of human methods so that it might stimulate imagination and thus help to further fulfil the creative potential of both artist and viewers. His mechanical camerachild was a catalyst. The careful preparation of the catalyst is the essence of Snow's method.

Jack Chambers' art is about looking for history, both personal and collective, in visual metaphors, which haunt him like recurring dreams. He could be said to embody a particular kind of Canadian experimental style, a nostalgia for memories which may never have been there in reality; perhaps they were only ever expectations. This is an important feature of the mediating Canadian imagination - looking for a history which can never be found, which makes the looking into an act of displacement. Beyond process and effect, this is the active obsession of a voyeur with a social conscience. Chambers painted many Canadian signs, both literal and metaphoric. In one of his early works, Messengers Juggling Seed (1962), Chambers paints the body of a proud young mother with feet firmly planted upon the soil. Only her husband's head is painted (the household head) floating in a bubble. A child is displayed only as hands (dirty hands? helping hands? farm hands?) again in a bubble. These, and many more bubbles, give the painting the appearance of being underwater, or in the unconscious (both important symbols to surrealist artists); the ideal family smiles handsomely like 
some buried treasure waiting to be discovered, sending up bubble messages which float freely like dandelion seeds. And, this entire spectacle is presented on a round canvas (the family circle). In later paintings, for example, [Highway] 401 Towards London No. 1 (1968-69), he presents on canvas the stark, flat landscape of Western Ontario, the monotony of the highway's lines and road signs broken only by the unique formations in passing clouds.

Both of these kinds of imagery are combined in Chambers' film Circle $(1969,28 \mathrm{~min}$.). The film is tightly framed. In the first two-thirds of the film, all of the scenes take place either in one room of a house, or in the backyard. There are only two camera angles - over or on Chambers' shoulder. In the house, he shows photographs of the outside of the house, the front of it. We never see the front of the house on camera. We only ever get to see the back of it from the outside through the camera lens "directly". In the house, we hear other people but we do not see them. In the backyard, we see photos of mother and children. Who are these people? Chambers' wife? His mother? His children? Him and his peers, or his siblings? But we do not see these through the film lens "directly". What is discovered/filmed is the space of a room and the land behind the house. Some of the rest of the story is filled in with photos. But these only serve to whet the viewer's curiosity. What happened in this place? Where has the family gone? All the memories are there, but the reality of the house is stark and lonely. The house is not a home, but maybe it was once. There are only simulations of warmth, in the photos. These memories are not directly accessible even to the curious camera-mind. In the concluding section of the film the camera finally interacts with people and animals: a girl training a dog, a man, then a woman, working in a candy factory, people getting off of a train, then descending a staircase, people swimming, children playing, first in mud, then snow, then watching birds. A strange, seemingly disconnected sequence of images if you think of them in terms of our normal workaday activities. But they are connected by a luminous disc which persists intermittently in the upper right-hand corner of the film frame. ${ }^{4}$ This is the circle, closure, containment, safety, the security of the womb, which some theorists believe that we return to, or long to, again and again in our dreams. As a dream sequence, Chambers' array of image-activities need not be justified by the rules of conscious logic. In light of my present reflections, and Chambers' knowledge of experimental cinema, I 
must ask at this point, how much of this is Chambers' dream and how much is it the camera's?

Chambers' film entitled Hart of London contained newsreel footage of people and events long past. The details in the images gradually fades, until they are finally absorbed into light. Jack Chambers made this final film right after discovering that he was fatally ill with leukemia, as an icon of the ruthlessly harsh realities of change and disintegration. Chambers was style embodied after the fact. His art filled him with its loneliness. He became a document (or) of a stark landscape of hopes, dreams and memories. Chambers was a map of a Canadian mood, an attitude displaying as much ambiguity as a highway sign. Signs often seem flat and distant at first glance, but they contain a great deal of symbolic currency when probed more deeply; for road signs are, ultimately, reminders of one's status in relationship to a state. They are a measure of patriotism, as in, the ways in which one remembers a self in relationship to a place, a particular patch of land which becomes a unique vessel full of memories of a heritage.

Bruce Elder's cinema is the apex of state-of-the-camera-body technique. Elder's film technique makes the camera as flexible as a dancer and a poet simultaneously. Elder's genre has been described, along with Brakhage's, as the "poetry film". Yet as Bart Testa has pointed out, this description is "useful only to distinguish the form of his and others' works from the conventions of the story-film." 5 Elder's films are not easy fare for even the most secure of semioticians. Technique for this filmmaker is a wide-ranging repertoire of reflexive gestures, the purpose of which is to produce visual and speech effects so intense that we are transformed by the camera's memory as filtered through its stochastic imagination. Elder uses experimental cinema to wake us up existentially. He makes the viewer remember what it was like to have a living body, by bringing on synaesthesia in attentive viewers. Those who have the time and the energy to pay attention reap the reward of synthetically (re)living the history of human consciousness through (re)experiencing the breakdown of perceptual categories, no longer being able to keep track of whether the feeling they just received from the film was derived from sight or sound. In this way, his camera has not only grown up, it now has a profession - that of teacher to humans who have forgotten, not only our own history, but also our bodies, our senses.

One of the ways in which Elder achieves these effects is by continuing to work with notions of time introduced by his mentors Brakhage, Warhol and Snow. In one sense, his technique of 
attention is about "making the most of time". He explores how time has been used in Illuminated Texts. This film moves from idealism to traumatic cynicism. In the beginning was the womb, the experience of perfect oneness with Mother. Then came the brutal world of nasty young peers, who loved to strip one another of their dignity. Next, Elder shows men doing hard manual labour, and wrestling. Then, in retirement, people have more time to reflect, to fantasize, to philosophize. And then we die. Elder carries out this programme on many levels - individual, social, philosophical, technological, spiritual - culminating in the Holocaust. His filming of the bed-stalls at Auschwitz is a tortuous lament over good intentions ruined. All the books of philosophy that had been written, all of the poetry and painting that had been created, could not stop that hateful destruction. We are not only bombarded by powerful images in swift succession. There is a voice which begins to repeat, to chant "Is it far?" over and over, as the film proceeds towards its climax. We are left hanging, after inspecting the graves. The camera will not answer the question for us. Is it far to what? Is it far to memory? To death? To an inner life? To hope?

In Lamentations time is for robotic arms in factories, table dancers who work by the minute, market transactions, medieval clock towers, Mexican siestas, the continuing disintegration of the ruins of ancient civilizations. I have written elsewhere about Elder's use of historical maps in this film, and body-maps as a play of opposites: nostalgia for the past and the attempt to escape from the anguish of nostalgia through sexual contact, which only momentarily relieves the yearning. 6 Time is lost, never to be regained. There is no more time to make the most of. Time stopped, and died, along with history for Elder, when the Jews burned in the ovens. We wish once again to be human, but cannot be. Perhaps the camera can be a better version of human ideals. Elder is also interested in how the end of metaphysics coincided with the end of histery. Much of the voice-over for Lamentations comes from Heidegger's Being and Time which Elder takes up as a call to existential responsibility, hence his need to document what has been lost and what remains. Elder explains what was - the human — and what is - the machine - as the death of the physical body and the birth of a synthetic one. He charts the growth of the camera's life by using all of the experimental techniques employed by his mentors, as well as elaborating upon these and inventing new gestures. He shows us death and creative imagination reborn through technology which he has taught about the human capacity for destruction. 
Without a metaphysical foundation, Elder asserts that we are left A) with language as a pragmatic instrument and B) with an intense nostalgia for modernity. ${ }^{7}$ Elder documents this nostalgia with a camera that swirls like a bird who is in a crazy flying panic, a bird who has lost her nest full of young. Elder has taken away the metal legs of the camera, which it retained throughout Snow's films. Nor are the camera's movements replicatable. The camera has become a flexible torso, whose movements must (as yet) however be guided by a person who has muscular elasticity and a strong back. The camera has become Elder's dance partner; sometimes they do ballroom, sometimes jitterbug, sometimes modern ballet. They seem to generate filmeffects mutually. Elder has said that while moving through swift shooting sequences, he cannot grasp what the camera is recording. It is only in editing that he can discern what the camera has seen during the dance.

The post-modern household is a prime site for institutional and ideological reproduction. Communications technologies are used to maintain this reproductive structure. Yet the same technologies can be used to experimentally undermine this focus.

Every avant-garde artist is a constellation around which his or her works circulate in a complex inter-textual array. It is no longer sufficient to consider how an artist uses a medium. It is crucial to consider how media use artists, as, in the case of the experimental film camera, it has taken on a life of its own.

Avant-garde film is an artistic laboratory where work is being done which challenges present forms of theoretical analysis. I interpret experimental film as a creative technology which has been nurtured, that is, helped to discover its uniqueness by specific individual artists. That which I call experimental film is a body - a body of discovery. It is a specific kind of body, not organic, and not exactly textual; it is a composite of many influences. Textual theories (so often used in film studies) do not fit this film genre very well, because it is not exactly a text. It is a marginal body of work. Words being the predominant vehicles of social communication, mainstream filmmakers lead audiences through an often complex assemblage of images with a self-contained story, pronounced throughout the display of characters and/or narrators. Experimental cinema explores aspects of human consciousness not adequately expressed in words. It presents its themes in terms considered unorthodox by more traditional filmmakers. It is an artistic body which does not privilege narrative, turning its attention instead to neglected strategies and life forces. The Canadian experimental cinema is unique. Yet it emerged from continental and American frames 
of reference. The body of this cinema is not a body independent of other artistic bodies. Canadian experimental film is unique because it is an art which promotes synaesthesia; it includes instead of excluding; it absorbs instead of differentiating. It is a cinema which displays what has been left out of categories and definitions; it attempts to depict the indefinable features of human subjectivity such as daydreaming, dancing, or simple but subtle movements of the heart, for example, a sudden hesitation highly appropriate topics for a marginal art form in a country with a consciousness of mediation.

The experimental cinema has now produced a new entity, which has been nurtured through childhood and adolescence by Warhol, Snow and Elder. It has been taught human history, human language, human aesthetics. It has even recorded the lives, joys, sorrows and deaths of its contributing parent-artists Hollis Frampton and Jack Chambers. New cinematic devices can now teach us to remember things which many of us forgot that we knew, and this it can do because of its abundant memory for names, faces, emotions, idiosyncrasies. The discovery and development of this new camera-life form by avant-garde filmmakers is a significant contribution to social theory. It no longer seems appropriate to speak of human society as if it were a machine, now that we know something of the unique life which cameras can (be imagined to) have, separate and different from human life in many ways which we do not yet understand. In any case, perhaps it will be easier to learn more about human society, about what it means to be human in post-modern society, when we can do without confusing applications of industrial metaphors to human life - where they do not apply. Cameras are discovering their bodies, leaving us to (re)discover ours. ${ }^{8}$

Bishop's University

\section{NOTES}

1 A synopsis of Chelovek s knoapparatom [The Man with the Movie Camera] can be found in Seth Feldman's book Dziga Vertov: a guide to references and resources (Boston: G.K. Hall \& Go., 1979), 98-110. I am indebted to Professor Feldman for reading and commenting upon the first draft of this article, and for directing my attention to Vertov's films. Annette Michelson has also written on this film. See her essay "From Magician to Epistemologist," in The Essential Cinema, Vol. One, ed. P. Adam Sitney (New York: Anthology Film Archives and New York University Press, 1975) 95-111.

2 This is Mary Ann Caws' translation of a section from Saint-Pol-Roux's text Cinéma Vivant (Paris: Rougerie, 1972) 37. I became intrigued with the work 
of Saint-Pol-Roux while reading Caws' essay, "A Cinema of the Central Eye," to be found in her book The Eye in the Text (Princeton, New Jersey: Princeton University Press, 1981) 173-188. The quote is from page 177.

3 The original is to be found in Saint-Pol-Roux's "Liminaire," in Les Reposoirs (Paris: Rougerie, 1972) 27.

4 This circle of light has been analysed in detail by Bruce Elder in his essay "From Painting to Cinema: A Study of Jack Chambers' Circle," in Journal of Canadian Studies, Vol. 16, No. 1 (Spring 1981) 60-81. Elder has also written two other interesting essays on Chambers. See "Forms of Cinema, Models of Self: Jack Chambers' Hart of London," in Take Two, ed. Seth Feldman (Toronto: Irwin, 1984) 264-284; also "The Persistence of Vision: Jack Chambers' Paintings and Films," in Descant, Vol. 34-36 (Winter 198182) 227-243.

5 Bart Testa, "Intimations of Deprival: Dennis Lee's The Gods, Civil Elegies, and Bruce Elder's Illuminated Texts," paper delivered at the Conference on Canadian Literature and Canadjan Film, State University of California, (November 14, 1986, unpublished).

6 Loretta Czernis, "Elder: Artaud After Telsat," in The Canadian Journal of Political and Social Theory, Vol. 10, Nos. 1-2 (1986) 266-273.

7 From a conversation with Bruce Elder.

8 I am indebted to Gaile McGregor, Robert Belton and Bart Testa for their comments and encouragement.

\section{WORKS CITED}

Caws, Mary Ann. The Eye in the Text. Princeton: Princeton University Press, 1981.

Kroker, Arthur. Technology and the Canadian Mind: Innis/McLuhan/Grant. Montreal: New World Perpectives, 1984.

Sitney, P. Adams. The Essential Cinema. Vol. I. New York: Anthology Film Archives and New York University Press, 1975. 